\title{
White Pine Blister Rust in Vermont: Past, Present, and Concerns for the Future
}

\author{
D.R. Bergdahl ${ }^{1}$ and H.B. Teillon ${ }^{2}$
}

Additional index words. Cronartium ribicola, cultivars, incidence, Pinus $R$ ibes

SUMmarY. White pine blister rust (WPBR) (C ronarti um ribicola J. C. Fischer) has been present in Vermont and other northeastern states since the early 1900s. The fungus is commonly observed on currants and gooseberries ( $R$ i bes L.) every year, but incidence varies on eastern white pine (Pinusstrobus L.). 0 ur general impression has been that Vermont has had a relatively low level of infection on eastern white pines; however, we recently found rust incidence in C hristmas tree plantings in northern Vermont to range from 10 to $42 \%$ (average 20\%) based on 721 trees surveyed. Also, in pole-sized stands in southern Vermont, incidence ranged from 12 to $46 \%$ (average $32 \%$ ) and $76 \%$ of these trees had main stem infections. In the southern survey, $98 \%$ of wild ribes plants had varied amounts of both urediniospores and teliospores. These preliminary survey data suggest that incidence of WPBR may be more significant than previously thought and therefore, additional survey work is needed. We screened cultivars of $R$ i bes for susceptibility to WPBR. E ighteen cultivars were inoculated in the field with a mass collection of aeciospores of $C$. ribicola. The percentages of leaf area infected ranged from 0 to 49 for the urediniospore stage and from 0 to 55 for teliospores. The gooseberry (R ibesuva-cri spa L.) 'Welcome' had the highest percentage of leaf area with urediniospores, while black currants (R . nigrum L.) 'C oronet,' 'C onsort,' and 'C rusader' had no visible infection. Presently, Vermont has no WPBR regulations. H owever, previous federal laws did restrict black currant cultivation. Little is known about the genetic diversity of WPBR or its potential for change. Caution must be used when considering any cultivation of $R$ ibes for the purpose of producing fruit because our valued white pine resources could be negatively impacted.

W hite pine blister rust caused by C ronartium ribicola (Arthur, 1934) needs no introduction to foresters or plant pathologists. It has a wellknown history as a destructive exotic pathogen in both Europe and $\mathrm{N}$ orth America. This rust is the main cause of timber loss for certain species of white pine [eastern white pine, sugar pine (Pinuslambertiana D ougl.) and western white pine (P. monticola D ougl. ex D. D on)] and has been responsible for creating major ecological change in the pine forests of $\mathrm{N}$ orth America (H agle et al., 1989; Ketcham et al., 1968; M errill, 1988; M ielke, 1943).

In northeastern N orth America, eastern white pine forests remain a highly significant part of the landscape and rural economy. In Vermont, the 1998 growing stock stumpage value of eastern white pine was estimated to be about $\$ 290$ million with an annual postharvest value of about $\$ 56.13$ million. In addition, pines have a substantial value associated with the ornamental and nursery trade (unpublished data). Therefore, we should consider eastern white pine as having a diversity of multiresource values important to our value-added forest industries and our rural economy.

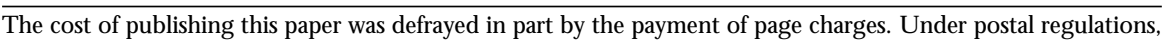
this paper therefore must be hereby marked advertisement solely to indicate this fact.

${ }^{1}$ Professor of forest pathology, D epartment of Forestry, U niversity of Vermont, Burlington, VT 05405.

${ }^{2}$ Chief of forest protection, Vermont D epartment of Forests, Parks, and Recreation, Waterbury, VT 05671.
} 
In addition, this species is invaluable; it adds substantial diversity and aesthetic interest to the picturesque hardwood forests and landscapes of our state.

WPBR is a heteroecious fungus that alternates between five-need le soft pines and $R$ ibes (Arthur, 1934). This rust has been known in $\mathrm{N}$ orth America since about 1900, but some pines and $\mathrm{R}$ ibes may have been infected prior to 1900 in northeastern N orth America (Benedict, 1981; Spaulding, 1911). WPBR was first reported in Vermont on nursery stock in 1909 (Spaulding, 1911). Therust is commonly observed on $\mathrm{R}$ ibes annually but rust incidence on pines seems to vary by year and geographical location. O ur general impression has been that eastern white pines have had a relatively low incidence of infection when growing in forested areas in Vermont (unpublished data).
Vermont has no current WPBR control regulations that restrict $R$ ibes $\mathrm{H}$ owever, previous laws did restrict the growing of black currant although other specieswereallowed if thegrower could certify that no valuable white pines grew within $900 \mathrm{ft}(274 \mathrm{~m})$ of the planting site. Vermont previously required shipping permits for all instate and out-of-state movement of $\mathrm{R}$ ibesbut this requirement wasdropped in 1996. These permits were primarily designed to inform the public about the serious nature of WPBR but they also provided a record of nursery sales of $\mathrm{R}$ ibes. Vermont also mandated a $\mathrm{R}$ ibesfree zone around their state tree nursery until it closed in 1994.

Genetic diversity of WPBR and its potential for change is not well understood. The commercial cultivars of $\mathrm{R}$ ibes are also genetically diverse and should be considered exotic plants when introduced to the landscape.
These cultivars are selected for hardiness, growth robustness, fruitfulness, and in some instances disease resistance. $M$ any of these cultivars may appear resistant to the current races of WPBR but it is unknown how resistance will change over time. These cultivars have potential to interbreed with native populations or with other cultivars of R ibes, and progeny from these out-crosses will be disseminated across the landscape and may bear little resemblanceto their parentage in terms of growth habit or disease resistance.

WPBR continues to cause serious damage to all species of susceptible pines throughout their respective ranges in $\mathrm{N}$ orth America (Kinloch and D ulitz, 1990). Because of concern for the long-term health of our native pines and due to the recent interest by small fruit growers in planting exotic cultivars of currants and gooseberries,

T able 1. Incidence of white pine blister rust on C hristmas tree-sized eastern white pine in northern Vermont, August 1999. All trees were sheared annually and had basal pruning except plots 3 and 5.

\begin{tabular}{|c|c|c|c|c|c|c|c|c|c|}
\hline \multirow[b]{3}{*}{ Plot } & \multirow{3}{*}{$\begin{array}{l}\text { Trees } \\
\text { (no.) }\end{array}$} & \multirow{2}{*}{\multicolumn{2}{|c|}{ Infection }} & \multicolumn{3}{|c|}{ I nfection type } & \multirow{3}{*}{$\begin{array}{c}\text { Total } \\
\text { infections } \\
\text { (no.) }\end{array}$} & \multirow{3}{*}{$\begin{array}{c}\text { Total } \\
\text { infections/ } \\
\text { infected } \\
\text { tree } \\
\text { (no.) } \\
\end{array}$} & \multirow{3}{*}{$\begin{array}{c}\text { Tree } \\
\text { size } \\
\left.\text { (ft }^{2}\right)\end{array}$} \\
\hline & & & & \multirow{2}{*}{$\begin{array}{c}\text { Twigs } \\
\text { (no.) }\end{array}$} & \multirow{2}{*}{$\begin{array}{c}\text { B ranches } \\
\text { (no.) }\end{array}$} & \multirow{2}{*}{$\begin{array}{c}\text { Stems } \\
\text { (no.) }\end{array}$} & & & \\
\hline & & no. & $\%$ & & & & & & \\
\hline 1 & 119 & 10 & 10 & 0 & 11 & 8 & 19 & 1.6 & $6-10$ \\
\hline 2 & 131 & 50 & 38 & 0 & 86 & 21 & 107 & 2.1 & $6-9$ \\
\hline 5 & 319 & 48 & 15 & 1 & 73 & 18 & 92 & 1.9 & $6-10$ \\
\hline 6 & 50 & 12 & 24 & 4 & 9 & 6 & 19 & 1.6 & $7-8$ \\
\hline Total & 721 & 142 & 20 & 6 & 204 & 60 & 270 & 1.9 & --- \\
\hline A verage & & & & $2 \%$ & $76 \%$ & $22 \%$ & & & \\
\hline
\end{tabular}

$\mathrm{z} 1 \mathrm{ft}=0.3 \mathrm{~m}$.

T able 2. Incidence of white pine blister rust on pole-sized eastern white pine in southern Vermont, August 1999.

\begin{tabular}{|c|c|c|c|c|c|c|c|c|c|}
\hline \multirow[b]{3}{*}{ Plot } & \multirow{3}{*}{$\begin{array}{l}\text { Trees } \\
\text { (no.) }\end{array}$} & \multirow{2}{*}{\multicolumn{2}{|c|}{ Infection }} & \multicolumn{3}{|c|}{ Infection type } & \multirow{3}{*}{$\begin{array}{l}\text { Total } \\
\text { infections } \\
\text { (no.) }\end{array}$} & \multirow{3}{*}{$\begin{array}{c}\text { T otal } \\
\text { infections/ } \\
\text { infected } \\
\text { tree } \\
\text { (no.) }\end{array}$} & \multirow{3}{*}{$\begin{array}{c}\text { Tree } \\
\text { size } \\
\left(\mathbf{f t}^{\mathbf{z}}\right)\end{array}$} \\
\hline & & & & \multirow{2}{*}{$\begin{array}{l}\text { Twigs } \\
\text { (no.) }\end{array}$} & \multirow{2}{*}{$\begin{array}{c}\text { B ranches } \\
\text { (no.) }\end{array}$} & \multirow{2}{*}{$\begin{array}{c}\text { Stems } \\
\text { (no.) }\end{array}$} & & & \\
\hline & & no. & $\%$ & & & & & & \\
\hline 1 & 24 & 10 & 42 & 0 & 4 & 9 & 13 & 1.3 & $10-20$ \\
\hline 2 & 24 & 7 & 29 & 0 & 0 & 7 & 7 & 1.0 & $25-50$ \\
\hline 5 & 24 & 11 & 46 & 0 & 1 & 11 & 12 & 1.1 & $20-50$ \\
\hline 6 & 24 & 3 & 12 & 0 & 1 & 2 & 3 & 1.0 & $20-50$ \\
\hline 7 & 24 & 4 & 17 & 0 & 0 & 5 & 5 & 1.2 & $20-40$ \\
\hline 8 & 24 & 8 & 33 & 2 & 2 & 4 & 8 & 1.0 & $5-40$ \\
\hline Total & 192 & 62 & 32 & 2 & 15 & 54 & 71 & 1.1 & --- \\
\hline
\end{tabular}

\footnotetext{
${ }^{\mathrm{z}} 1 \mathrm{ft}=0.3 \mathrm{~m}$.
} 
Table 3. Incidence of white pine blister rust on wild R ibes species in southern Vermont, August 1999.

\begin{tabular}{lccccl}
\hline Plot & $\begin{array}{c}\text { Plants } \\
\text { (no.) }\end{array}$ & $\begin{array}{c}\text { Stems } \\
\text { (no.) }\end{array}$ & $\begin{array}{c}\text { Infected } \\
\text { plants } \\
\text { (no.) }\end{array}$ & $\begin{array}{c}\text { Infection } \\
\text { (\%) }\end{array}$ & $\begin{array}{l}\text { Site } \\
\text { surveyed }\end{array}$ \\
\hline 1 & 12 & 26 & 12 & 100 & Stonewall near road \\
2 & 11 & 21 & 11 & 100 & Stonewall near road \\
3 & 5 & 14 & 5 & 100 & Stonewall near road \\
4 & 7 & 53 & 7 & 100 & Stonewall/ hedge \\
5 & 6 & 16 & 6 & 100 & Stonewall \\
6 & 1 & 3 & 1 & 100 & Stonewall/ hedge \\
7 & 4 & 8 & 4 & 100 & Stonewall/ hedge \\
8 & 4 & 11 & 3 & 75 & Roadside wet area \\
Total & 50 & 152 & 49 & --- & \\
Average & 6.2 & 3.0 & --- & 98 & \\
\hline
\end{tabular}

zU redia and telia present.

we designed a preliminary survey to assess incidence of WPBR. In addition, we studied relative WPBR susceptibility of certain R ibes cultivars. The main objectives of this paper are to present these findings and to express concern about the future of our white pine resource in the presence of $\mathrm{R}$ ibes and WPBR.

\section{Materials and methods}

In August 1999, we conducted a preliminary survey to determine the relative incidence of WPBR on living eastern white pine trees and native $R$ ibes species. A total of six survey sites were located in Christmas tree plantations in northern Vermont and an additional eight sites were in naturally regenerated stands in the south. A transect method was used to survey trees at each site. All trees were evaluated for number of WPBR infections (twig, branch, and main stem) and tree heights (feet) were estimated. All trees from a randomly selected row of trees were evaluated in each of the six northern plantations but only the first 24 trees in a $66 \mathrm{ft}$ ( $20.1 \mathrm{~m}$ ) wide transect were evaluated at each site in the south. We also evaluated the incidence of WPBR on native populations of $R$ ibes using a transect method but restricted the survey to habitats conducive for growth of R ibes (i.e., stone walls and moist areas).

In 1988, we screened 18 Ribes cultivars (see Table 4) for relative susceptibility to WPBR and a brief abstract was published (Dorrance and Bergdahl, 1990). All cultivars were grown in the field at Jericho, $\mathrm{Vt}$., and were initially inoculated in early $M$ ay with a mass collection of aeciospores collected from three different cankers from each of five different grographical regions in Vermont. Thereafter, all new infections were the result of natural infection in the field. To evaluate susceptibility, five leaf samples were randomly collected from each cultivar during mid-J uly and late August and the percentage of leaf area covered by urediniospores or teliospores was determined for those dates, respectively. Analysis of variance and D uncan'smultiple rangetest were used to determine significance of these leaf area data.

\section{Results and discussion}

WPBR is commonly observed on $R$ ibesevery year but incidence of infection seems to vary on eastern white pine. This variation may be due to the influence of the many environmental parameters affecting the epidemiology of WPBR (Charlton, 1963; Van Arsdel, 1965). I n our recent survey (August 1999), we found rust incidence in Christmas tree plantings in northern Vermont to range from 10 to $42 \%$ (average 20\%) based on 721 trees surveyed (Table 1 ). In total, $22 \%$ of the infected trees had lethal main stem infections; whereas, $76 \%$ and $2 \%$ of the trees had branch and twig infections, respectively. In southern Vermont, incidence of infection ranged from $12 \%$ to $46 \%$ (average $32 \%$ ), and $76 \%$ of the infected treeshad main stem infections; whereas, $21 \%$ and $3 \%$ of thetrees had branch and twig infections, respectively (Table2). The average number of infections per infected tree was 1.1 for the older trees in the south as compared to 1.9 for northern trees. Branch infections may eventually becomelethal main stem infections once thefungus hastheopportunity to grow through an infected branch into the main stem. Therefore, the much higher percentage of main stem infections on the older trees in southern Vermont is most likely the result of the fungus having sufficient time to grow into the main stem.

O ur survey resultssuggest WPBR may be more significant in Vermont than previously thought. We are especially concerned about the high percentage of potentially lethal main stem infections found on the older pines. Based on these preliminary results, we believe that a more comprehensive survey is needed and should be designed to determine both incidence and severity of WPBR in the major eastern white pine growing regions of our state. This more comprehensive survey should be designed to serve as a baseline for incidence of WPBR infection prior to any proposed commercial planting of $\mathrm{R}$ ibeswithin our pine forest regions.

The incidence of infection was also recorded for all species of wild $\mathrm{R}$ ibesfound along survey transectsonly in southern Vermont. About $98 \%$ of the surveyed plants were infected with WPBR and all had both urediniospores and teliospores present by late August 1999 (Table 3). These wild plants were generally found growing in the understoryalong stonewallsor in moist soils. Thesewild plants werenot vigorous (averagethreestemsper plant) nor were they highly fruitful in comparison to commercial cultivars.

Of the $18 \mathrm{R}$ ibescultivarsscreened in mid-J uly, the gooseberry 'Welcome' had the highest percentage of leaf area affected with urediniospores; while black currants 'Coronet,' 'Consort,' and 'C rusader' had no visible infection (Table 4) (Dorrance and Bergdahl, 
1990). The gooseberries 'R edjacket' and 'Pixwell' had the highest percentage of leaf area with teliospores; while the red currents ( $R$. rubrum L.) 'Cherry' and 'Consort' had no apparent infection ( $T$ able 5). The black currants 'C ornet,' and 'C rusader;' the red currant 'Wilder;' and the gooseberries (R . uva-crispa), 'C anada0273', 'G reen

T able 4. Percentage of leaf area with urediniospores of C ronartium ribicola on cultivars of $R$ ibes.

\begin{tabular}{lc}
\hline Cultivar & $\begin{array}{c}\text { Leaf } \\
\text { area }^{2} \\
(\%)\end{array}$ \\
\hline Welcome & $49 \mathrm{a}^{\mathrm{y}}$ \\
Redjacket & $31 \mathrm{~b}$ \\
Green H ansa & $28 \mathrm{bc}$ \\
Poorman & $26 \mathrm{bc}$ \\
Wilder & $20 \mathrm{bcd}$ \\
Champion & $20 \mathrm{bcd}$ \\
Pixwell & $15 \mathrm{bcd}$ \\
Canada 0273 & $14 \mathrm{bcd}$ \\
Spinefree & $14 \mathrm{bcd}$ \\
Whitesmith & $10 \mathrm{~cd}$ \\
Friedl & $9 \mathrm{~cd}$ \\
Red Lake & $6 \mathrm{~d}$ \\
Jumbo & $4 \mathrm{~d}$ \\
Cherry & $4 \mathrm{~d}$ \\
White Currant & $3 \mathrm{~d}$ \\
Consort & $0 \mathrm{~d}$ \\
Crusader & $0 \mathrm{~d}$ \\
Coronet & $0 \mathrm{~d}$ \\
\hline
\end{tabular}

${ }^{\mathrm{z} B}$ ased on five leaves per plant.

ypercentagesfollowed by the sameletter are not significantly different using D uncan's multiple range test ( $p$ $=0.05$ ).

T able 5. Percentage of leaf area with teliospores of Cronartium ribicola on cultivars of Ribes $L$.

\begin{tabular}{lc}
\hline Cultivar & $\begin{array}{c}\text { Leaf } \\
\text { area }^{\mathbf{z}} \\
\mathbf{( \% )}\end{array}$ \\
\hline Redjacket & $55 \mathrm{a}^{\mathrm{y}}$ \\
Pixwell & $46 \mathrm{ab}$ \\
Welcome & $25 \mathrm{~b}$ \\
Poorman & $24 \mathrm{bc}$ \\
Spinefree & $9 \mathrm{bc}$ \\
Friedl & $8 \mathrm{bc}$ \\
Jumbo & $7 \mathrm{bc}$ \\
Red Lake & $6 \mathrm{bc}$ \\
White Currant & $4 \mathrm{bc}$ \\
Champion & $1 \mathrm{c}$ \\
Cherry & $0 \mathrm{c}$ \\
Consort & $0 \mathrm{c}$ \\
\hline
\end{tabular}

\footnotetext{
zBased on five leaves per plant.
}

ypercentages followed by the sameletter are not significantly different using D uncan's multiple range test ( $p$ $=0.05$ ).
$\mathrm{H}$ ansa' and 'Whitesmith', were completely defoliated by lateA ugust. Their leaf area with teliospores could not be evaluated.

Resistance to WPBR in certain whitepine phenotypeshasbeen known since about 1950 and disease resistance breeding programs have been in placesincethat time (Bingham, 1983). However, the genetics and mechanisms of disease resistance are yet to be understood and evidence is mounting concerning genetic variation in the pathogen ( $\mathrm{H}$ amlin, 1998; $\mathrm{M} \mathrm{CD}$ onald and D ekker-Robertson, 1998). I $n$ addition, various cultivars of $R$ ibes have substantial phenotypic variation in WPBR resistance (Anderson and French, 1955; D orranceand Bergdahl, 1990; H ummer, 1997). Some commercial cultivars of $\mathrm{R}$ ibesappear highly resistant to this pathogen but the nature of this resistance and its transferability to other species or cultivars is not understood.

Early attempts to slow the spread of WPBR were primarily aimed at controlling R ibespopulations. This control effort was finally determined not to be efficacious in western North America and wasdiscontinued in 1966 (Ketchum et al., 1968); however, reductions in $\mathrm{R}$ ibespopulations have been reasonably successful in controlling WPBR on eastern white pine (L aflamme et al., 1998; O strofsky et al., 1988).

Eastern white pines are a longlived, valuable resource in the forests of $\mathrm{N}$ orth America. WPBR is a virulent exotic pathogen that is lethal to most white pines but not to Ribes Currently, the possibility of growing commercial cultivars of $R$ i besfor small fruit production is being discussed. We believe that such an endeavor would be very risky for eastern white pines based on current understanding of the genetic, epidemiological, and host-parasiterelationships of WPBR. O ur major concerns about the future potential of WPBR in the presence of its hosts include but are not limited to the following:

1) Commercial $R$ ibescultivarsarenot part of the natural ecosystem and therefore should be considered exotic plant introductions. These cultivars may produce offspring (seeds or pollen) that could be disseminated into forested areas. The resulting plants could eventually become a factor in the epidemiology of WPBR. Progeny from some WPBR-resistant cultivars are not resistant to this rust (G. H udler, personal communication). Also, littleisknown about the diversity and pathogenicity of the different races of $C$. ribicola on the different species and cultivars of $\mathrm{R}$ ibes. We think this is an area that will require a substantial amount of research.

2) The planting of WPBR resistant $R$ ibes cultivars will provide additional selection pressure on $\mathrm{C}$. ribicola. Thispressurewill eventually elicit and select for change in the pathogen. This change may havea significant, negative impact on either or both of its hosts. Also, the many so-called resistant cultivars may not be resistant to all strains of $C$. ribicola. This is also an area that will require substantial study.

3) Forest industry hashad little if any involvement in thisdiscussion concerning the proposed commercial production of $R$ i besas a fruit crop. We think the value of white pine will far exceed the values associated with growing $\mathrm{R}$ ibes fruit. Therefore, it isveryimportant that the growers of susceptible white pines be involved in all phases of this WPBR/ R ibes discussion.

4) We think selected R ibes cultivars could begrown if they werehighly resistant or immune to WPBR and onlycould beasexually propagated (i.e., no viable seed or pollen produced). However, any form of apomixisisunknown in the genus $\mathrm{R}$ ibes at this time but cultivars of thistype possibly could beplanted without risk to susceptible white pines for as long as WPBR resistance was maintained by these cultivars. O nce resistance is lost, these cultivars would need to be removed from production areas.

5) Dueto theseriousnature ofWPBR and its significant potential for a negative impact on our highly valued pine resource, we think it is in the best interest of all to be cautious when considering the commercial production of $\mathrm{R}$ ibes fruit in our forested areas.

\section{Literature cited}

Anderson, R.L., and D.W. French. 1955. Evidence of races of $C$ ronartium ribicola on R ibes. For. Sci. 1:38-39. 
Arthur, J.C. 1934. M anual of rusts in U nited States and Canada. Purdue Res. Found., L afayette, Ind.

Benedict, W.V. 1981. H istory of white pine blister rust control-A personal account. U SD A For. Serv. FS 355.

Bingham, R.T. 1983. Blister rust resistant western white pine for the I nland $E$ mpire: The story of the first 25 years of the research and development program. U SD A For. Serv. I nterM t. For. Range Expt. Sta. (O gden, U tah) Gen. T ech. R pt. I N T-146.

Charlton, J.W. 1963. Relating climate to eastern white pine blister rust infection hazard. U SD A For. Serv. N .E. For. Expt. Sta.

D orrance, A.E. and D.R. Bergdahl. 1990. Screening of commercial cultivars of $\mathrm{R}$ ibes spp. for susceptibility to Cronartium ribicola. Phytopathology 80:118-119.

H agle, S.K., G.L. MCD onald, and E.A. Norby. 1989. White pine blister rust in northern Idaho and western Montana: Alternatives for integrated management. USDA For. Serv. Gen. Tech. Rpt. INT261.

H amlin, R.C. 1998. M olecular epidemiology of white pineblister rust. Proc. 1st I ntl. Union For. Res. O rg. Rusts of Forest T rees WP Conf., 2-7 Aug., Saariselka, Finland. Finnish For. Res. Inst. Res. Papers 712:255-259.

H ummer, K. 1997. D iamonds in the rust: Ribes resistance to white pine blister rust. Fruit Var. J. 51(2):112-117.

Ketcham, D.F., C.A. Wellner, and S.S. Evans. 1968. Western white pine management programs realigned on northern Rocky M ountain national forests. J. For. 66:329-332.
Kinloch, Jr., B.B., and D. Dulitz. 1990. White pine blister rust at $\mathrm{M}$ ountain $\mathrm{H}$ ome D emonstration State Forest: A case study of the epidemic and prospectsfor genetic control. U SD A For. Serv. Res. Paper PSW 204.

Laflamme, G., R. Blais, and D. D esgagne. 1998. Control of Cronartium ribicola in Pinus strobus plantations. Proc. 1st Intl. U nion For. Res. O rg. Rusts of Forest T rees WP Conf., 2-7 Aug., Saariselka, Finland. Finnish For. Res. Inst. Res. Papers712:299303.

M cD onald, G.I. and D.L. DekkerRobertson. 1998. Long-term differential expression of blister rust resistance in western white pine. Proc. 1st Intl. U nion For. Res. O rg. Rusts of Forest Trees WP Conf., 2-7 Aug., Saariselka, Finland. Finnish For. Res. Inst. Res. Papers 712:285-295.

M errill, W. 1988. White pine blister rust: $A$ brief summary of its history, host range and distribution, disease cycle, host-parasite relationships, damage caused, rate of disease increase, and control. A report. N.E. For. Pest Council, Albany, N.Y.

M ielke, J.L. 1943. White pine blister rust in western N orth America. Yale U niv. School For. Bul. 52.

O strofsky, W.D., T. Rumpf, D. Struble, and R. B radbury. 1988. Incidence of white pine blister rust in $\mathrm{M}$ aine 70 years after a $\mathrm{R}$ ibes eradication program. Plant Dis. 72:967970.

Spaulding, P.C. 1911. The blister rust of white pine. U SDA Bul. 206.

Van Arsdel, E.P. 1972. Environment in relation to white pine blister rust infection, p. 479-493. In: Biology of rust resistance in forest trees. Proc. N AT O-IU FRO Advanced StudyI nst., 17-24 Aug. 1969. U SD A M isc. Publ. 1221. 